\title{
TELAAH HUKUM ISLAM TENTANG LGBT \\ (SEBUAH SOLUSI DALAM MEMECAHKAN \\ PROBLEM KEMASYARAKATAN)
}

DAHLIA HALIAH MA'U

Fakultas Syari'ah IAIN Pontianak

Alamat email: lystia.lia@gmail.com

\begin{abstract}
The Lesbian, Gay, Bisexual, and Transgender (in Indonesia known as LGBT) are fahisyah (bad/nasty) behaviors that are clearly probibited in Islam. Those behaviors were performed by Prophet Luth people in the past and be included in Quran and Hadith. The fuqaha agreed that the behaviors are forbidden for Moslems since the negative impact to the doers and societies. Furthermore, the Islamic Law has categrized the punishmet to those who practice the behaviors. First, the doer would be killed or rajam (being thrown with stones until death). Second, the similar punishment to people who practice adultery or free sex (zina); If the doer is married (mubsan), the sanction is rajam, and if the doer is not married yet (ghaim mubsan), he/ she would be whipped a hundred times. Third, the performer of those behaviors would be punished by the government or a judge (ta'zir), the level of the sanction would be decided by the government or a judge fairly. Moreover, the government, ulama, and societies have an important role to avoid these nasty behaviors through the implementation of the rules formally, and verbal persuasion.
\end{abstract}

Keywords: LGBT, Liwath, Rajam, Dera, Ta'æir, Mashlahah.

\section{PENDAHULUAN}

Syari'at (hukum Islam) bersifat universal, mengatur seluruh aspek kehidupan manusia, baik dalam hubungannya dengan Tuhan, maupun sesama manusia dan alam. Dalam praktiknya syari'at Islam senantiasa memperhatikan kemaslahatan manusia, dengan mengajak setiap pengikutnya untuk mematuhi perintah dan larangannya. Hukum Islam akan menindak tegas para pelaku yang melanggar ketentuan dan peraturan yang telah ditetapkan berdasarkan nash al-Qur'an dan hadis. Prinsip ini merupakan suatu yang esensial dan faktual dalam menangani problem yang terjadi dalam masyarakat Islam (Syaltut, 1968: 12).

Syari'at Islam berasal dari wahyu Allah Swt. Oleh karena itu, syari'at yang diturunkannya juga mempunyai satu sistem. Artinya, hukum-hukum yang dikandung syari'at Islam tersebut tunduk pada satu landasan dan tujuan, sehingga ketentuan-ketentuannya pun seragam, tidak bertentangan antara satu dengan lainnya.Dalam hal ini, Islam membawa ajaran yang lengkap, mencakup seluruh aspek kehidupan.Tidak satupun aspek hidup dan kehidupan umat manusia yang lepas dari perhatian Islam.Diantara aspek kehidupan yang sangat penting yang di atur Islam adalah hubungan biologis atau seks.

Seks merupakan suatu hal yang bersifat sakral dan harus disalurkan secara benar dan bermoral melalui pernikahan.Penyaluran seks di luar nikah disebut zina yang merupakan pelanggaran yang amat tercela. Akhir-akhir ini, perilaku seks berupa zina, homoseksual, lesbian, dan berbagai perilaku aneh dalam hal seks ini, lagi marak dibahas oleh masyarakat Indonesia, baik melalui media elektronik, 
cetak, maupun melalui seminar dan diskusi. Istilah yang berkembang dalam perilaku seks dan perilaku aneh tersebut dinamakan dengan term LGBT (Lesbian, gay, biseksual, dan transgender).

Perilaku LGBT yang dilakukan sejumlah orang mengundang kontroversi (pro dan kontra) serta polemik pada kalangan masyarakat luas, baik secara internasional maupun nasional. Kalangan yang mendukung (pro) LGBT berdalih pada Hak Asasi Manusia (HAM), sedangkan kalangan yang tidak mendukung (kontra) berdalih pada aturan agama dan moral. Pro-kontra ini, bisa jadi diakibatkan karena kurangnya pemahaman masyarakat tentang hal ini, padahal persoalan ini justru berkaitan dengan ketentraman masyarakat. Problem inilah yang mengantarkan penulis untuk mengkaji perspektif agama (hukum Islam) tentang LGBT. Perlu digarisbawahi bahwa penulis lebih fokus mengkaji LGBT dalam konteks yang lebih spesifik yakni perilaku lesbian dan gay (homoseksual), sedangkan biseksual dan transgender telah mencakup pada kedua makna tersebut, karena berkaitan dengan perilaku seks menyimpang yang dilakukan oleh manusia.

\section{GAMBARAN NORMATIF PERILAKU HOMOSEKSUAL DALAM ALQUR'AN DAN HADIS}

Perilaku gay atau homoseksual telah dikenal masyarakat dari masa ke masa. Pada kurun waktu tertentu perilaku ini dilakukan oleh kaum Nabi Luth as.Al-Q ur'an al-Karim telah menggambarkan sifat-sifat kaum Nabi Luth yang tidak mau mengawini perempuan, sebagaimana terdapat dalam QS.at A'raf (7): 80-84.

"Dan (Kami juga telah mengutus) Luth (kepada kaummya) (ingatlah) tatkeala dia berkata kepada mereka "Mengapa kamu mengerjakean perbuatan fahisyah itu, yang belum pernah dikerjakanoleh seorangpun (di dunia ini) sebelummu?". Sesungguhnya kamu mendatangi lelaki untuk melepaskan nafsumu (kepada mereka), bukan kepada wanita, kamu ini adalah kaum yang melampani batas. Jawab kaumnya tidak lain hanya mengatakan: "Usirlah mereka (Luth dan pengikutpengikutnya) dari kotamu ini, sesunggubnya mereka adalah orang-orang yang berpura-pura mensucikan diri”. Kemudian Kami selamatkan dia dan pengikut pengikutnya kecuali isterinya, dia termasuk orang-orang yang tertinggal (dibinasakan).Dan Kami turunkan kepada mereka bujan (batu), maka perhatikanlah bagaimana kesudahan orangorang yang berdosa itu’'.(Departemen Agama RI, 1995: 234235).

Ridha (1950, Kairo: 511-513) memaparkan bahwa Nabi Luth di utus Allah Swt untuk memperbaiki aqidah dan akhlaq kaumnya yang berdiam di negeri Sadum, Amurah, Adma', Sabubim, dan Bala', di tepi laut mati. Nabi Luth memilih tinggal di negeri yang paling besar dari kelima negeri

${ }^{1}$ Dalam Kamus Besar Bahasa Indonesia (2007: 157 dan 665), hanya ditemukan istilah Lesbian dan Biseksual. Sedangkan istilah gay dan transgender tidak terdapat dalam kamus ini. Lesbian diartikan dengan wanita yang mencintai atau merasakan rangsangan seksual sesama jenisnya atau wanita homoseks. Sedangkan, biseksual memiliki dua pengertian yaitu: mempunyai sifat kedua jenis kelamin (laki-laki dan perempuan) dan tertarik kepada kedua jenis kelamin (baik kepada laki-laki maupun perempuan). Istilah gay terdapat pada kamus bahasa Inggris yang berarti homoseksual. Sedangkan transgender berarti laki-laki yang menyerupai perempuan (banci) atau perempuan yang menyerupai laki-laki (waria).Menurut penulis, beberapa istilah tersebut dapat didefinisikan sesuai dengan pemahaman masyarakat saat ini yakni; lesbian adalah perilaku perempuan yang senang berhubungan seks dengan sesama perempuan.Gay atau homoseksual adalah perilaku laki-laki yang senang berhubungan seks dengan sesama laki-laki. Biseksual adalah perilaku perempuan atau laki-laki yang senang berhubungan dengan sesama jenis atau lawan jenisnya.Sedangkan, transgender adalah banci atau waria. Adapun istilah transeksual merupakan bagian dari kategori transgender yang melakukan operasi kelamin. 
itu yaitu Sadum. ${ }^{1}$ Negeri Sadum mengalami kehancuran moral, kaum laki-laki lebih bersyahwat kepada sesama jenisnya yang berusia muda dan tidak bersyahwat kepada kaum wanita. Ketika menyaksikan perbuatan kaumnya yang tidak bermoral tersebut, Nabi Luth menegur dan memperingatkan kaumnya untuk meninggalkan kebiasaannya.Ia mengajak untuk menyalurkan naluri seks sesuai dengan fitrah yaitu melalui perkawinan antara pria dan wanita. Ajakan Nabi Luth ini dijawab oleh kaumnya dengan mengusir dari masyarakatnya.Sementara itu, mereka terus melakukan perbuatan keji dan tidak bermaksud meninggalkan kebiasaan buruk tersebut.

Senada dengan ungkapan di atas, menurut Qardhawi (t.th.: 194195),Nabi Luth menganggap perbuatan kaumnya sebagai permusuhan, kebodohan, berlebihan, rusak, dan dosa. Sikap yang lebih aneh dari mereka yang telah hilang akal pikirannya, moralnya bejat dan hasrat manusiawinya telah rusak adalah ketika mereka menyambut tamu Nabi Luth yang tidak lain adalah malaikat azab. Semua itu merupakan ujian bagi mereka dan satu metode untuk melestarikan momen mereka dalam sejarah kemanusiaan.

Kaitannya dengan adanya tamu Nabi Luth tersebut, sebagaimana dijelaskan dalam QS.Hud (11): 77-82.

"Dan tatkala datang utusan-utusan Kami (para malaikat) itu kepada Luth, dia merasa susah dan merasa sempit dadanya karena kedatangan mereka, dan dia berkata "ini adalah hari yang amat sulit".Dan datanglah kepadanya kaumnya dengan bergegasgegas.Dan sejak dabulu mereka selalu melakukan perbuatanperbuatan yang keji. Luth berkata: "Hai kaumku, inilah puteri-puteriku, mereka lebih suci bagimu, maka bertakwalah kepada Allah dan janganlah kamu mencemarkan (nama)ku terbadap tamuku ini. Tidak adakah di antaramu seorang yang berakal?". Mereka menjawab: "Sesunggubnyakami telah tabu bahwa kami tidak mempunyai keinginan terbadap puteri-puterimu, dan sesunggubnya kamu tentu mengetabui apa yang sebenarnya kami kehendaki." Luth berkata: "Seandainya aku mempunyai keekuatan (untuk menolakmu) atau kalau aku dapat berlindung kepada keluarga yang kuat (tentu aku lakukan)”. Para utusan (malaikat) berkata: "Hai Luth, sesunggubnya kami adalah utusan-utusan Tubanmu, sekali-kali mereka tidak akan dapat mengganggu kamu, sebab itu pergilah dengan membawa keluarga dan pengikutpengikut kamu di akbir malam dan janganlah ada seorangpun di antara kamu jang tertinggal, kecuali istrimu. Sesunggubnya dia akan ditimpa azab yang menimpa mereka karena sesunggubnya saat jatubnya azab kepada mereka ialah di waktu subuh, bukankah subuh itu sudah dekat?". Maka tatkala dating azab Kami, Kami jadikan negeri kaum Luth itu yang di atas ke bawah (Kami balikekan), dan Kami bujani mereka dengan batu dari tanah yang terbakar dengan bertubi-tubi'.(Departemen Agama RI, 1995: 339-340).

Beberapa ayat al-Qur'an lainnya yang membuktikan kekejian perilaku kaum Nabi Luth as dan gambaran azab (hukuman) yang ditimpakan kepada mereka sebagaimana terdapat dalam QS.alAnbiya' (21): 7475, QS. asy-Syu'ara (26): 160- 175 QS. an-Naml (27): 5458, QS. al-Qamar (54): 3339, QS. al-Hijr (15): 57-77, 70-72, dan QS. an-Najm (53): 54.Adapun hadis Nabi Saw yang berkaitan dengan perilaku homoseksual, diantaranya adalah:

Pertama, hadis dari Ibnu Abbasyang menjelaskan bahwa Rasul Saw bersabda:

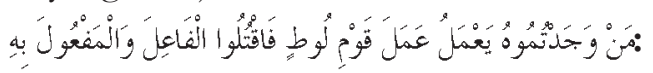

${ }^{1}$ Dalam Ensiklopedi Hukum Islam (1996: 563) disebutkan bahwa kaum Nabi Luth as berdomisili di negeri Sodom (di sebelah Timur Laut Mati atau sekarang di Yordania), dan karena itu di kalangan bangsa Barat yang beragama Kristen, perbuatan demikian disebut sodomi. 
"Barangsiapa yang kalian dapati melakukan perbuatan kaum Luth, maka bunuhlah kedua pelakunya”. (Abu Dawud, Juz. XIII, 1416/1996: 131).

Kedua, hadis dari Ibnu Abbas, bahwa Nabi Saw berkata:

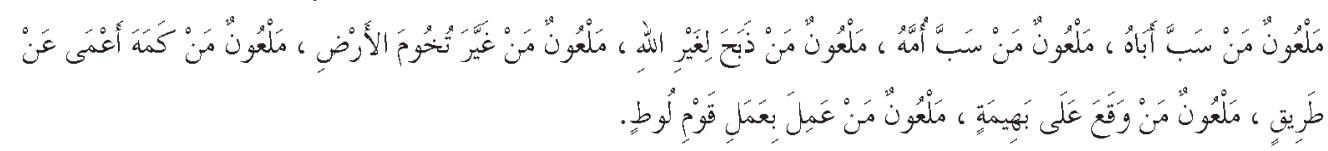

“Terlaknatlah orang yang mencela ayahnya, terlaknatlah orang yang mencela ibunya, terlaknatlah orang yang menyembelih (hewan) bukan karena Allah, terlaknatlah orang yang merubah batas tanah, terlaknatlah orang yang membisu (tidak mau memberi petunjuk) terhadap orang yang buta yang mencari jalan,terlaknatlah orang yang menyetubuhi binatang dan terlaknatlah orang yang berbuat seperti perbuatan kaum Luth.”(Ahmad bin Hanbal, Juz. I, 1419 H / 1998 M: 217).

Ketiga, hadis dari Jabir bin Abdullah, bahwa Rasul Saw bersabda:

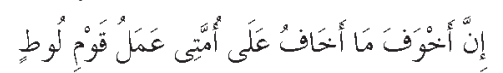

“Sesungguhnya yang paling aku takuti (menimpa) umatku adalah perbuatan kaum Luth" (Sunan at-Turmuzi, Juz. VI, t.th.:41).

Keempat, hadis dari Ibnu Abbas, bahwa Nabi Saw berkata:

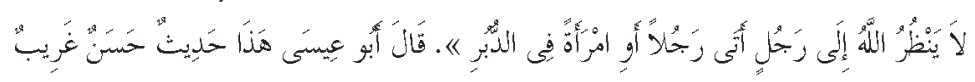

“Allah tidak akan melihat kepada laki-laki yang menyetubuhi laki-laki atau menyetubuhi wanita pada duburnya” (Sunan at-Turmuzi , Juz.V t.th.: 9).

Berdasarkan beberapa hadis di atas, dapat dipahami bahwa Rasulullah Saw sangat mengkhawatirkan umatnya melakukan perbuatan tercela tersebut, sebagaimana perbuatan kaum Nabi Luth. Bahkan, jika terdapat umatnya yang melakukan perbuatan tercela tersebut, maka pelakunya harus dibunuh.

\section{PERSPEKTIF FUQAHA TENTANG LGBT}

Hukum Islam menyebutkan homoseks antara sesama pria dengan istilah liwath, ${ }^{1}$ sebagai kata yang akar katanya sama dengan akar kata luth. Perbuatannya disebut dengan liwath karena perbuatan tersebut pernah dilakukan oleh kaum yang durhaka kepada seruan Nabi Luth as.

Homoseks (liwath) dan yang berkaitan dengannya merupakan perbuatan keji dan termasuk dosa besar. Homoseks juga termasuk salah satu perbuatan yang merusak unsur etika, fitrah manusia, agama, dunia, bahkan merusak kesehatan jiwa. Allah Swt telah mengecam homoseks dengan siksa yang maksimal. Allah Swt telah membalikkan bumi terhadap kaum Luth yang telah keterlaluan melakukan homoseks. Dan Allah Swt telah menghujani batu yang menyala kepada mereka sebagai balasan atas perbuatan mereka yang menjijikkan tersebut (Sabiq, t.th. : 272).

Berkaitan dengan hukum homoseksual di atas, ash-Shabuni (1994: 87) menyatakan perbuatan durjana tersebut adalah puncak dari pada segala keburukan dan kekejian. Kita hampir tidak mendapatkan seekor binatang jantan mengawini seekor binatang jantan lainnya. Akan tetapi,

${ }^{1}$ Liwath atau homoseksual ialah persetubuhan antara seorang laki-laki dengan laki-laki lain (ash-Shabuni, 1994: 86). 
keganjilan tersebut justru terdapat di antara manusia.Oleh sebab itu, maka dapatlah dikatakan bahwa keganjilan tersebut merupakan suatu noda yang berhubungan dengan moral yaitu suatu penyakit psikhis yang berbahaya yang mencerminkan suatu penyimpangan dari fitrah manusia, yang mengharuskan untuk di ambil tindakan yang keras terhadap pelakunya.

Fuqaha telah sepakat ${ }^{1}$ atas keharaman homoseks dan pelakunya diberikan sanksi (hukuman) yang berat. Keharaman ini, sesuai dengan kaidah fiqh "al-ashlu fi al-ibdha'i at-tabrim", hukum asal pada masalah seks adalah haram. Maksud dari kaidah ini adalah dalam hubungan seks, asalnya adalah haram, sehingga ada sebab-sebab yang jelas dan tanpa meragukan lagi yang menghalalkannya yaitu dengan adanya akad pernikahan (Djazuli, 2007: 122).

Dalam hal ini, para fuqaha berbeda pendapat tentang sanksi (hukuman) bagi pelaku homoseksual tersebut. Menurut az-Zuhaili (1422 H / 2002 M: 66-67)terdapat empat kategorisasi pemikiran fuqaha tentang hukuman bagi pelaku homoseks (liwath) yaitu:

1. Imam Malik, Imam Syafi'i, dan Imam Ahmad bin Hanbal menyatakan bahwa tindakan liwath mewajibkan seseorang mendapatkan hukuman hadd'.Karena Allah Swt memperberat hukuman bagi pelakunya dalam kitab-Nya. Sehingga pelakunya harus mendapatkan hukuman hadd zina karena adanya makna perzinaan di dalamnya.

2. Imam Abu Hanifah berpendapat, orang yang melakukan liwath hanya di hukum $\operatorname{ta}^{\prime} \mathbf{z i r}^{3}$ saja. Karena tindakan liwath tidak sampai menyebabkan percampuran nasab, dan biasanya tidak sampai menyebabkan perseteruan yang sampai berujung pada pembunuhan pelaku, dan liwath sendiri bukanlah termasuk zina.

3. Ulama Malikiyah dan ulama Hanabilah mengemukakan bahwa pelakunya dihukum rajam ${ }^{4}$, baik pelakunya berstatus mubshan (telah menikah) maupun ghairu mubshan (belum menikah). Pendapat ini di dasarkan pada hadis Nabi Saw yang diriwayatkan oleh Abu Dawud (Juz.XIII, t.th. :131):

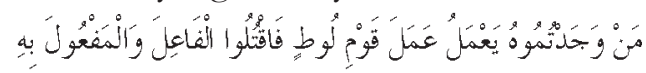

"Jika kamu sekalian mendapati orang yang melakukan perbuatan kaum Luth, bunuhlah orang yang menjadi subjek (pelakunya) dan yang menjadi objeknya (yang diperlakukan)".

4. Ulama Syafi'iyah berpandangan hukuman haddbagi pelaku liwath adalah sama dengan hukuman hadd zina. Jikapelaku berstatus mubshan, maka wajib di rajam. Sedangkan, jika pelakunya berstatus

${ }^{1}$ Kesepakatan fuqaha menjadi konsensus seluruh umat Islam.Dalam hal ini, dalam masalah fundamental harus merupakan kesepakatan seluruh umat dan pada persoalan sekunder cukup ijma sebagian ulama (Hasan, 2015: 41). Menurut penulis, persoalan penyelewengan seksual adalah persoalan yang fundamental karena aturan normatifnya telah jelas dalam al-Qur'an dan hadis.

${ }^{2} \mathrm{Hadd}$ atau hudud adalah kejahatan yang sanksi hukumannya telah ditetapkan secara pasti oleh Allah Swt atau Nabi Saw. Jenis kejahatan yang termasuk dalam lingkup hadd adalah: perzinaan, tuduhan zina tanpa bukti, pencurian, perampokan, minum-minuman keras, makar / pemberontakan, dan murtad(Syarifuddin, 2003: 256).Hukuman atau hadd zina yang dikenakan pada pelaku zina muhshan (duda, janda, laki-laki yang masih beristri atau perempuan yang masih bersuami) adalah wajib di rajam sampai mati. Terdapat juga fuqaha yang berpendapat hukuman bagi pelaku zina mubshan adalah didera (dipukul) sebanyak seratus kali dan dirajam sampai mati (Sabiq, t.th.: 261).Adapun hukuman atau hadd zina yang dikenakan pada pelaku zina ghairu mubshan (jejaka atau perawan)adalah dera (dipukul) sekaligus diasingkan selama satu tahun ke suatu kawasan dengan jarak yang sudah memperbolehkan untuk mengqashar shalat. (az-Zuhaili, 1422 H / 2002 M: 39).

${ }^{3}$ Ta'zir adalah kejahatan lain yang tidak diancam dengan hukuman qishash-diyat (tindak kejahatan yang sanksi hukumannya adalah balasan setimpal serta denda) dan tidak pula dengan budud. Dalam hal ini jenis hukumannya ditetapkan oleh imam atau penguasa atau pemerintah (Syarifuddin, 2003: 257).

${ }^{4}$ Rajam adalah jenis hukuman dalam bentuk dilempar dengan batu yangberukuran sedang sampai mati (Syarifuddin, 2003: 280). 
ghairu mubshan, maka wajib dicambuk dan diasingkan. Hal ini di dasarkan pada satu hadis yang diriwayatkan oleh Abu Musa al-Asyari ra, bahwasanya Rasul Saw bersabda: "Apabila seorang lakilaki mendatangi laki-laki, maka kedua-duanya telah berzina. Dan apabila seorang perempuan mendatangi perempuan, maka kedua-duanya telah berzina”. Alasan lainnya dari kalangan ini adalah karena hukuman hadd liwath adalah hukuman hadd yang disebabkan oleh tindakan persetubuhan, maka harus dibedakan antara pelaku yang berstatus mubshan dan ghairu mubshan, karena diqiyaskan dengan hukuman hadd zina dengan persamaan keduanya sama-sama tindakan memasukkan alat kelamin yang diharamkan ke dalam kemaluan orang lain yang diharamkan.

Senada dengan deskripsi di atas, al-Jaziri (1410 H/1990 M: 113) mengemukakan bahwa para fuqaha sepakat atas keharaman liwath (homoseks) menurut ketentuan syari'at. Liwath merupakan perbuatan keji (fahisyah) sebagaimana jarimah zina, keduanya termasuk dosa besar dan merupakan perbuatan yang tidak sesuai dengan fitrah manusia.

Berdasarkan paparan di atas, dapat dipahami bahwa fuqaha telah sepakat atas keharaman liwath, hanya saja fuqaha berbeda pendapat tentang jenis hukuman bagi pelakunya, dalam hal ini terdapat tiga jenis hukuman atau sanksi pagi pelaku perbuatan fahisyabini, yakni: 1). dibunuh dalam bentuk di hukum rajam(jenis hukuman dalam bentuk dilempar dengan batu sampai mati) baik dilakukan oleh mubshanmaupun ghairu muhshan).Hal ini sesuai dengan hadis yang diriwayatkan oleh Abu Dawud "Jika kamu sekalian mendapati orang yang melakukan perbuatan kaum Luth, bunublah orang yang menjadi subjek (pelakunya) dan yang menjadi objeknya (yang diperlakukan)”.2). disamakan dengan sanksi bagi pelaku zina, yakni apabila yang melakukan liwath adalah mubshan, maka pelakunya di hukum rajam, jika pelakunya ghairu mubshan maka di dera (cambuk) seratus kali. 3). dihukum ta' zir (jenis hukuman yang diserahkan kepada pemerintah atau hakim). Dengan demikian, berat ringannya sanksi tersebut sangat ditentukan oleh pemerintah atau hakim.

Merujuk pada ketiga jenis hukuman di atas (dibunuh, rajam / dera, dan ta'rir), penulis beranggapan bahwa ketiga jenis hukuman tersebut dapat dilakukan sesuai dengan tingkat perbuatan seseorang dalam hal liwath. Artinya, jika jenis hukuman teringan masih bisa dilakukan dan membuat efek jera bagi pelaku, maka jenis hukuman tersebut yang diterapkan. Tapi, jika pelaku telah melakukan berkali-kali dan tidak dapat dihentikan perbuatannya dengan jenis hukuman teringan, maka berlaku hukuman rajam dan dera baginya. Hanya saja, jenis hukuman berupa rajam dan dera sangat sulit di terapkan di Indonesia (kecuali provinsi Aceh yang telah menerapkan aturan hukum pidana Islam).Oleh karena itu, pemerintah perlu membuat aturan yang dapat menyadarkan pelaku liwath untuk kembali ke fitrahnya. Tentunya, aturan agama harus menjadi acuan normatif, sehingga nilainilai kemaslahatan manusia dapat terwujud dengan baik.

\section{NILAI KEMASLAHATAN PELARANGAN LGBT DAN SOLUSINYA}

Islam sebagai agama rahmatan lil 'alamin telah mengatur berbagai aturan hidup manusia. Aturan hidup tersebut sangat berkaitan dengan hajat hidup manusia yang tujuannya untuk kemaslahatan dan ketentraman manusia itu sendiri. ${ }^{1}$ Dalam hal ini juga, Islam telah mendidik setiap individu agar dapat

${ }^{1}$ Pentingnya menciptakan kemaslahatan dan ketentraman bagi manusia dalam tujuan hukum Islam disebut dengan istilah maqhashid as-syari'ah.Menurut al-Rasyuni (1981: 18-19), maqhashid as-syari'abadalah tujuan syari'ah dan rahasia-rahasia yang telah ditetapkan oleh al-Syari' (Tuhan) dalam setiap ketentuan hukum-hukumnya.Maqhashid secara umum adalah memelihara aturan, menarik kemaslahatan, menolak kerusakan, menegakkan persamaan di antara umat manusia dan menjadikan syari'ah (hukum Islam) sebagai suatu hukum yang berwibawa dan ditaati. 
menjadi sumber kebaikan bagi masyarakatnya, tidak menjadi keburukan yang akan merugikan orang lain.

Sabiq (t.th.: 273) memaparkan bahwa perbuatan homoseks dapat merusak jiwa. Dan kegoncangan yang terjadi dalam diri seorang pelaku homoseks adalah karena ia merasakan adanya kelainan-kelainan perasaan terhadap kenyataan dirinya. Dalam perasaannya, ia merasa sebagai seorang wanita, sementara kenyataan organ tubuhnya adalah laki-laki, sehingga ia lebih simpati atau jatuh cinta kepada orang yang sejenis dengan dirinya untuk pemuasan libido seksualnya. Karena itu, banyak juga pemuda yang terjerumus dalam dunia homoseks. Mereka suka bersolek seperti wanita dengan menggunakan make up, cara berpakaian, cara berjalan dan bergaul, dan sebagainya.

Lebih lanjut Sabiq (t.th.: 275) menyatakan: homoseks adalah suatu perbuatan tercela yang merusak unsur akhlaq dan merupakan suatu penyakit jiwa yang berbahaya. Orang yang keranjingan homoseks, pasti berakhlaq jelek, tabiatnya bejat, serta ia hampir-hampir tak dapat membedakan mana yang baik dan mana yang buruk. Selain itu, orang yang keranjingan homoseks pada umumnya lemah dan tak punya nafsu kekuatan batin, serta tidak mempunyai unsur batin yang dapat mengendalikan perbuatannya. Dengan demikian, ia tega menumpahkan nafsu seksualnya yang abnormal kepada anak-anak kecil dengan menggunakan kekerasan.

Umat Islam dan manusia pada umumnya, seharusnya mengambil hikmah dari peristiwa yang terjadi pada kaum Nabi Luth. Akibat perilaku homoseks yang mereka lakukan, maka Allah Swt menyiksa mereka di dunia dengan gempa bumidisertai hujan batu dari tanah yang terbakar (lihat QS. Hud (11): 82).Kaitannya dengan siksa yang menimpa kaum Nabi Luth ini (sebagaimana gambaran QS. Hud (11): 82, Shihab (2002: 316) mendeskripsikan bahwa ayat tersebut, disamping memberi gambaran tentang kehancuran total, juga mengesankan persamaan sanksi tersebut dengan kedurhakaan mereka (kaum Nabi Luth). Bukankah mereka juga memutarbalikkan fitrah.Seharusnya pelampiasan syahwat dilakukan dengan lawan seks, tetapi mereka membaliknya menjadi homoseks. Seharusnya ia dilakukan dengan penuh kesucian, tetapi mereka menjungkirbalikkan dengan penuh kekotoran dan kekejian.

Seirama dengan beberapa pernyataan di atas, imam asy-Syaukani dalam ash-Shabuni (1994: 87) memaparkan, alangkah layaknya bagi orang yang melakukan perbuatan durjana ini dan mempraktikkan pekerjaan yang rendah lagi terhina tersebut diberi hukuman yang menjadi pelajaran bagi mereka yang suka mengambil pelajaran, serta memperoleh siksaan yang mematahkan nafsu syahwat orang-orang fasik, pelanggar kemanusiaan. Sungguh tepat bagi orang yang mengerjakan perbuatan keji suatu kaum yang belum pernah dikerjakan oleh seorangpun dari umat-umat sebelum kaum ini, untuk mendapat hukuman yang berat dan kerasnya menyerupai berat dan kerasnya siksaan yang dijatuhkan pada kaum itu, yaitu bahwa Allah telah membenamkan mereka ke dalam bumi dan membinasakan mereka sampai kepada akar-akarnya.

Larangan homoseks dan lesbian yang disamakan dengan perbuatan zina dalam ajaran Islam, bukan hanya karena merusak kemuliaan dan martabat kemanusiaan, tetapi resikonya lebih jauh lagi, yaitu dapat menimbulkan penyakit kanker kelamin, AIDS, dan sebagainya. Tentu saja perkawinan waria yang telah menjalani operasi penggantian kelamin dengan laki-laki, dikategorikan sebagai praktik homoseksual, karena tabiat kelaki-lakiannya tetap tidak bisa diubah oleh dokter, meskipun ia sudah memiliki kelamin perempuan buatan (Mahjuddin, 2003: 28). 
Banyak sekali argumen keagamaan yang melarang perilaku homoseks / lesbian, dan semacamnya (sebagaimana telah dijelaskan sebelumnya).Dengan demikian, dapat dikatakan bahwa pelaku homoseks dan sejenisnya dapat membawa bencana di zaman modern ini.Sebagai salah satu bukti akibat dari perilaku homoseks, lesbian, zina,pekerja seks komersial, dan lain-lain adalah munculnya berbagai penyakit seperti HIV dan AIDS. ${ }^{1}$ Dikhawatirkan juga, jika perilaku buruk ini merajalela, maka bisa jadi musibah dahsyat yang melanda kaum Nabi Luth akan menimpa kepada para pelaku tersebut serta umat yang tidak peduli dengan larangan syari' (pembuat hukum) atau justru lebih dahsyat lagi musibah tersebut, karena peristiwa tersebut sudah diabadikan dalam atQur'an, tapi para pelaku tidak mengambil ibrah (pelajaran) darinya.

Rasulullah Saw dalam kapasitasnya sebagai pemimpin agama dan pemimpin negara telah memberikan warning kepada umat Islam melalui sabdanya yang diriwayatkan oleh Imam Muslim(1415/1995: 219):

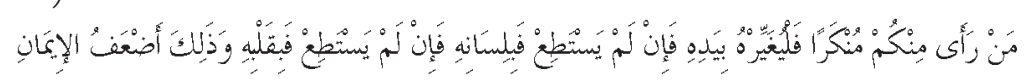

"Barangsiapa melibat kemungkaran, maka rubahlah/cegahlah dengan tangannya (kekuasaan), maka apabila tidak mampu (maka rubablab) dengan lisannya, dan jika tidak mampu, maka (rubablab) dengan bati (do'anya), yang demikian itu adalah selemah-lemah iman'.

Hadis di atas menunjukkan bahwa pencegahan terhadap kemungkaran dilakukan sesuai dengan kemampuan.Ulil amri (pemerintah) adalah orang yang memiliki kekuasaan untuk mencegah terjadinya kemungkaran berupa perilaku homoseks, lesbian, dan sebagainya.Dengan kekuasaannya, ulil amri dapat membuat aturan tentang pelarangan dan sanksi bagi para pelaku perbuatan tidak terpuji ini.Adapun yang bisa mencegah dengan lisannya adalah para ulama / kyai / ustadz / tokoh agama / ilmuwan, dan masyarakat. Selanjutnya jika tindakan preventif pertama dan kedua telah dilaksanakan dan belum berhasil, maka langkah terakhir adalah pencegahan dengan hati yang bisa dilakukan berupa doa atau perasaan berontak dan keinginan yang kuat untuk bertindak tetapi tidak mampu (artinya, membenci perbuatan fahisyah tersebut). Jika pencegahan melalui doa ini juga tidak dilakukan oleh umat Islam, maka hal ini menunjukkan bahwa kadar iman seseorang telah hilang dari hatinya.

Langkah-langkah yang ditempuh di atas merupakan sebuah wujud dari ajaran tolong menolong yang telah digariskan agama. Dapat dikatakan bahwa jika seseorang menyelamatkan sesama manusia dengan jalan mencegahnya dari perilaku yang merusak, maka ia telah melakukan suatu bentuk pertolongan dalam hal yang baik. Sebaliknya, jika seseorang mendukung perilaku buruk (menyimpang) yang dilakukan manusia, maka ia dianggap turut membantu sesamanya dalam hal yang buruk. Padahal agama telah menggariskan dalam QS.al-Maidah (5): 2; "Dan tolong-menolonglah kamu dalam (mengerjakan) kebaikan dan takwa, dan jangan tolong-menolong dalam berbuat dosa dan pelanggaran. Dan bertakwalah kamu kepada Allah, sesungguhnya Allah amat berat siksa-Nya".

${ }^{1}$ Berdasarkan Pusat Data dan Informasi Kemenkes RI (2014: 1-4) Jumlah kumulatif kasus HIV/AIDS di Indonesia semakin bertambah dari tahun ke tahun. Berdasarkan data statistik kasus HIV/AIDS di Indonesia yang dilaporkan Direktorat Jenderal Pemberantasan Penyakit Menular dan Penyehatan Lingkungan Kemenkes RI tahun 2014, menunjukkan secara kumulatif HIV/AIDS 1 April 1987 s.d 30 Sepetember 2014 adalah 55.799 orang dengan rincian penderita HIV 150.296 orang, penderita AIDS 55.799, dan kematian 9.796 orang. Dari jumlah kumulatif tersebut diketahui pula, bahwa jumlah kumulatif kasus AIDS paling banyak menyerang usia produktif 20-29 tahun. Selain itu disebutkan pula 10 provinsi kasus HIV/AIDS terbanyak yaitu DKI Jakarta, Jawa Timur, Papua, Jawa Barat, Bali, Sumatera Utara, Jawa Tengah, Kalimantan Barat, Kepulauan Riau, dan Sulawesi Selatan. 


\section{PENUTUP}

Merujuk pada hasil kajian ini, maka penulis merumuskan beberapa hal sebagai kesimpulan yaitu,--LGBT merupakan perbuatan fabisyah (buruk/keji) yang merupakan puncak keburukan yang berkaitan dengan nafsu syahwat manusia. Perbuatan ini tidak hanya berkaitan dengan moral, tapi berkaitan juga dengan penyakit psikhis yang berbahaya dan menyimpang dari fitrah manusia. Islam sebagai agama yang sarat dengan nilai-nilai kemanusiaan dan fitrah insani, telah memberikan gambaran yang jelas tentang perilaku buruk ini melalui perilaku kaum Nabi Luth dan secara jelas menggambarkan azab yang dahsyat bagi para pelakunya.-- Para fuqaha telah sepakat atas keharaman perbuatan ini (homoseksual, lesbian, dan berbagai perilaku seks yang dilakukan di luar lembaga pernikahan yang sah). Keharaman tersebut, berdampak pada sanksi (hukuman) sebagaimana gambaran dari al-Qur'an, hadis, dan ijma' fuqaha. Klasifikasi hukumannya terdiri atas tiga pendapat: Pertama,dibunuh dalam bentuk di hukum rajam.Kedua,disamakan dengan sanksi bagi pelaku zina, yakni apabila yang melakukan liwath adalah mubshan, maka pelakunya di hukum rajam, jika pelakunya ghairu mubshan maka di dera (cambuk) seratus kali. Ketiga, dihukum ta'zir (jenis hukuman yang diserahkan kepada pemerintah atau hakim), berat ringannya sanksi tersebut sangat ditentukan oleh pemerintah atau hakim.- Agar perbuatan keji ini tidak merajalela dalam masyarakat makaulil amri(pemerintah) dengan kekuasaannya dapat membuat aturan tentang pelarangan dan sanksi bagi para pelaku perbuatan tidak terpuji ini. Selanjutnya, para ulama / kyai / ustadz / tokoh agama/ilmuwan, dan masyarakat, dapat mencegah dengan lisannya. Kemudian, jika tindakan preventif pertama dan kedua telah dilaksanakan dan belum berhasil, maka langkah terakhir adalah pencegahan dengan hati yang bisa dilakukan siapapun yakni berupa doa atau perasaan berontak artinya membenci perbuatan fahisyah tersebut, tapi hal ini menunjukkan bahwa kadar iman seseorang telah hilang dari hatinya atau menunjukkan lemahnya iman seseorang.

\section{REFRENSI}

Abu Dawud, Abu Dawud Sulaiman bin al-Asy'as as-Sijistani.1416/1996. Sunan Abi Dawnd, Tahqiq Muhammad 'Abdul Aziz al-Khalidi, Juz VIII,Beirut-Libanon: Dar al-Kutub al-'Tlmiyah.

Ahmad bin Hanbal, Abu Abdullah Ahmad bin Muhammad.1419 H / 1998 M.Musnad Ahmad bin Hanbal, Juz I, Beirut: 'Alim al-Kutub.

Ahmad, al-Rasyuni. 1981.Ną̧hryat al-Maqhashid Inda al-Imam al-Syathibi, Riyadh: Dar al-'Alamiyah li al-Kitab al-Islami wa al-Ma'had al-'Alami al-Fikr al-Islami.

Dahlan, Abdul Aziz, dkk. 1996.Ensiklopedi Hukum Islam, jilid 2, Jakarta: Ichtiar Baru Van Hoeve.

Departemen Agama RI. 1995. Al-Qur'an dan Terjemahnya, Semarang: Alwah.

Departemen Pendidikan Nasional. 2007. Kamus Besar Bahasa Indonesia, Jakarta: Balai Pustaka.

Djazuli, H.A. 2007. Kaidah-Kaidah Fikih, Jakarta: Kencana.

Hasan, Muhammad. 2015. Analisis Historis Kategorisasi Ushul Fiqh dan Implikasinya, dalam jurnal al-Maslahah, vol.11 No. 1. April 2015. IAIN Pontianak: Fakultas Syari'ah dan Ekonomi Islam.

al-Jaziri, Abdurrahman.1410 H/1990 M. Kitab al-Figh 'Ala al-Madrabib al-Arba'ah. Juz V, BeirutLibanon: Dar al-Kutub al-'Ilmiyah.

Mahjuddin. 2003. Masailul Fiqhiyah, Jakarta: Kalam Mulia. 
Muslim bin Hajjaj, Abu Husain al-Qusyairy an-Naisaburi. 1415/1995. Sahih Muslim, Syarah anNawawi, Juz I, Beirut: Dar Ihya at-Turats al-'Arabi.

Pusat Data dan Informasi Direktoral Jenderal Pelayanan Medik Direktorat Jenderal Pemberantasan Penyakit Menular dan Penyehatan Lingkungan, Kemenkes RI, “ Statistik Kasus HIV/AIDS di Indonesia tahun 2014".

Qardhawi, Yusuf. t.th.Halal dan Haram dalam Islam, penerjemah: Achmad Sunarto, Surabaya: Karya Utama.

Ridha, Rasyid. 1950. Tafsir al-Manar, Kairo: Mathba'ah al-Hajari.

Sabiq, Sayyid. t.th. Fiqh al-Sunnah, Juz II, Kairo: al-Fath Lil I'lam al-'Arabiy.

ash-Shabuni, M. Ali. 1994. Tafsir Ayat-Ayat Hukum dalam Al-Qur'an, penerjemah Saleh Mahfoed, jilid 2, Bandung: al-Ma'arif.

Shihab, M.Quraish. 2002. Tafsir al-Mishbah,Jakarta: Lentera Hati, volume 6.

Syarifuddin, Amir. 2003. Garis-garis Besar Fiqh, Jakarta: Kencana.

Syaltut, Mahmud. 1968. Al-Islam Aqidah wa Syariah, Mesir: Dar al-Qalam.

at-Turmuzi, Muhammad bin Isa bin Saurah bin Musa. t.th.al-Jami' as-Sabih Sunan Tirmiri, syarah: Ahmad Muhammad Syakir, Juz V dan VI, Beirut: Dar Ihya at-Turats al-'Araby.

az-Zuhaili, Wahbah. 1422 H / 2002 M. Al-Fiqh al-Islami wa Adillatubu, Juz VI, Mesir: Dar al-Fikr. 